\title{
Checking the landing zone: Do invertebrate larvae avoid settling near superior spatial competitors?
}

\author{
Stephan G. Bullard ${ }^{1,3}$, Robert B. Whitlatch ${ }^{1, *}$, Richard W. Osman ${ }^{2}$ \\ ${ }^{1}$ Department of Marine Sciences, University of Connecticut, Groton, Connecticut 06340, USA \\ ${ }^{2}$ Smithsonian Environmental Research Center, PO Box 28, 647 Contees Wharf Road, Edgewater, Maryland 21037, USA \\ ${ }^{3}$ Present address: University of Hartford Hillyer College, 200 Bloomfield Av., West Hartford, Connecticut 06117, USA
}

\begin{abstract}
It has been hypothesized that larvae of benthic marine invertebrates may reduce their risk of post-settlement competition by avoiding superior competitors during settlement. Few studies, however, have directly compared the levels of larval settlement close to and away from established competitors. We conducted experiments in the New England subtidal to determine whether larvae of fouling organisms would avoid substrata $\left(100 \mathrm{~cm}^{2} \mathrm{PVC}\right.$ panels) with established adult colonies of the tunicates Botryllus schlosseri, Botrylloides violaceus, and Diplosoma listerianum compared to control substrata without tunicates. After panels had been exposed for $1 \mathrm{wk}$ in the field, we assessed larval settlement on the entire surface of panels and within $1 \mathrm{~cm}$ of established tunicate colonies. We also monitored the fate of larvae that settled near established tunicates to determine if different tunicate species posed different risks of overgrowth to newly settled juveniles. Pair-wise comparisons revealed only 1 significant difference (out of 48 total analyses) when we examined levels of settlement on panels with tunicates relative to bare controls. We also found no significant differences in the number of settlers overgrown by different tunicate species. Thus, our results suggest that invertebrate larvae do not avoid settling near established dominant competitors (i.e. colonial tunicates). These results are in contrast to a previous study which had shown that larvae of competitively inferior species avoided settling near $B$. schlosseri.
\end{abstract}

KEY WORDS: Ascidians · Competition · Cues · Larvae $\cdot$ Overgrowth $\cdot$ Settlement · Tunicates Resale or republication not permitted without written consent of the publisher

\section{INTRODUCTION}

Many benthic marine invertebrates include a dispersive larval stage in their life histories. Although larvae are planktonic, they must undergo settlement before assuming the final benthic adult form. Settlement is a particularly critical period of the larval life span (Pechenik 1999). When settling larvae enter benthic habitats, they must not only contend with unfamiliar predators and physical factors, but they must also find a suitable settlement site (Stoner 1990, 1994). Because many marine invertebrates are sessile as adults, the settlement site selected by a larva will become the permanent home of the adult organism. Thus, the choice of settlement site made by a larva is critical to the future welfare of the organism (Keough \& Downes 1982, Hunt \& Scheibling 1997, Maldonado \& Uriz 1998).
To select among settlement sites, larvae of many species possess physiological mechanisms to detect physical or chemical cues that indicate substratum suitability (Meadows \& Campbell 1972, Pawlik 1992, Hadfield \& Paul 2001). Specifically, settlement cues indicate whether settlement sites have appropriate physical or biological conditions (e.g. substrate type and orientation, presence of prey, conspecific adults, predators, or competitors) for the adult organism (Young \& Chia 1981, Johnson \& Strathmann 1989, Hurlbut 1993, Toonen \& Pawlik 1996, Krug \& Manzi 1999, Kingsford et al. 2002). If a settlement site has acceptable cues, a larva will settle. If a site lacks appropriate cues, or possesses negative cues, the larva may reenter the water column and resume its search.

A significant biological factor that may affect the willingness of larvae to settle is the presence of established 
competitors on the substratum. In many hard-substrata benthic habitats, sessile organisms are abundant and space for attachment is a limiting resource. Thus, competition for space can be intense in these habitats (Branch 1984, Sebens 1986). To acquire space, many adult organisms overgrow or crush weaker spatial competitors (Connell 1961, Hunt \& Scheibling 1997). Other species release allelopathic chemical compounds that harm or kill competitors or their larvae (Thacker et al. 1998, Engel \& Pawlik 2000, Koh \& Sweatman 2000). At the species level, the outcome of spatial competition is often predictable, with some species almost always outcompeting others (Witman \& Dayton 2001, Barnes 2002). Therefore, organisms may increase their chances of survival by avoiding areas where superior spatial competitors exist. One mechanism that sessile species may use to avoid superior spatial competitors is the ability of their larvae to detect and avoid potential competitors during settlement (Grosberg 1981, Young \& Chia 1981).

The ability of settling larvae to avoid potential competitors has been documented in New England (USA) shallow-water fouling assemblages (Grosberg 1981). In New England fouling communities, the colonial tunicate Botryllus schlosseri (hereafter referred to as Botryllus) is one of the dominant competitors. Grosberg (1981) demonstrated that larvae of fouling species that were inferior spatial competitors to Botryllus avoided settling on substrata with established Botryllus juveniles, while larvae of fouling species with competitive abilities comparable to Botryllus settled at random.

Within the last $30 \mathrm{yr}$ the New England subtidal has been invaded by 2 additional species of colonial tunicates, Botrylloides violaceus and Diplosoma listerianum (Steneck \& Carlton 2001) (hereafter referred to as Botrylloides and Diplosoma). Both species are important spatial competitors and have competitive abilities roughly equivalent to Botryllus (Grosberg 1981 for Botrylloides, S. G. Bullard \& R. B. Whitlatch pers. obs. for Diplosoma; see also Nandakumar 1996 for a description of the strong competitive abilities of the congener Diplosoma mitsukurii). Since their introduction, these invasive tunicates have become very common and in some areas are among the most abundant fouling species (Osman \& Whitlatch 1995a,b, Steneck \& Carlton 2001).

The purpose of our investigation was to determine whether larvae of benthic invertebrates, especially species that are poor competitors, avoid settling on substrata with established colonies of the tunicates Botrylloides and Diplosoma as they have previously been shown to avoid Botryllus (Grosberg 1981). Testing this would allow us to further assess the idea that settling larvae can detect the presence of dominant competitors on the substratum. Additional tests of this hypothesis are warranted because direct evidence for this idea comes from a limited number of studies (i.e. Grosberg 1981, Young \& Chia 1981; see also Stebbing 1972, Barnett \& Crisp 1979, Dunstan \& Johnson 2004).

\section{MATERIALS AND METHODS}

This study was conducted in eastern Long Island Sound on floating docks adjacent to the University of Connecticut, Avery Point. Settlement substrata $(10 \times$ $10 \mathrm{~cm}$ PVC panels) with and without tunicates were exposed to naturally settling larvae for $1 \mathrm{wk}$ in the field (17 to 23 July 2002). Four treatments were deployed, including panels with a single established adult colony of Botryllus, Botrylloides, or Diplosoma, and controls without any tunicates. Data were collected for (1) the size of established tunicate colonies $\left(\mathrm{cm}^{2}\right.$ panel coverage) before and after exposure, (2) the number of larvae settling on the entire surface of each panel, (3) the number of larvae settling within $1 \mathrm{~cm}^{2}$ of established tunicate colonies, and (4) the number of settlers overgrown by established tunicate colonies. Results obtained from our experiment are directly comparable with those of Grosberg's (1981) study, because larval settlers at both study sites were composed of the same suite of species.

To prepare treatments, adult tunicate colonies were removed from epiphyte-encrusted kelp blades (Laminaria spp. collected near the study site) and transplanted to the center of individual PVC panels. To facilitate successful attachment, transplanted colonies were secured to panels with rubber bands and placed in flow-through seawater tables. Panels were examined after $48 \mathrm{~h}$ and those with attached colonies were used for assays. While some colonies failed to attach to panels, the attachment process did not appear to adversely affect the colonies and the survival of those that did attach was high. During the 1 wk experiment, 6 colonies died (1 Botryllus, 1 Botrylloides, and 4 Diplosoma) out of 60 total colonies deployed. All surviving colonies appeared healthy. Data were collected only for surviving colonies.

To establish the initial size of each tunicate colony, each panel was photographed with a digital camera (2.1 M pixel resolution) before the experiment was deployed. Digital images were analyzed to obtain colony surface area using NIH Image software.

Twenty replicate panels were deployed for each treatment. Panels were suspended from PVC pipes, positioned facing the seafloor, and hung $0.5 \mathrm{~m}$ below the surface of the water and about $2 \mathrm{~m}$ above the seafloor. Panels were arranged haphazardly so that adjacent panels were composed of different treatments (see Osman \& Whitlatch 1995a for additional details of panel construction and deployment techniques). 
Our goal was to examine whether larvae responded to the presence of established adult tunicates on the settlement substratum. However, larvae of our test species (i.e. Botryllus, Botrylloides, and Diplosoma) commonly settled on our panels. To ensure that newly settled tunicates did not compromise our treatments, every $24 \mathrm{~h}$ we returned the panels to the laboratory in seawater-filled coolers and counted and removed all newly settled Botryllus, Botrylloides, and Diplosoma. After tunicate settlers were removed, panels were returned to the field and redeployed. Panels remained in the laboratory for approximately $1.5 \mathrm{~h}$ for tunicate removal.

Larvae settling near established tunicates can be overgrown by the established colonies. To determine whether settlers faced different risks of overgrowth from different species of tunicate, we monitored overgrowth events for newly settled larvae. Every $24 \mathrm{~h}$ (while the panels were at the laboratory for the removal of tunicate settlers) we mapped the location and species of larvae that had settled near established tunicates. By comparing the maps of settled larvae from one day to the next, we could record the types and numbers of settlers that had been overgrown by adult tunicates; i.e. if we recorded a settler on our map one day and failed to find it the next day, we assumed that it had been overgrown. It is possible that these techniques caused us to overestimate settler mortality. However, we made the assumption that missing settlers were overgrown for several reasons. First, we could almost always see overgrown settlers underneath adult tunicates. Second, most of the settlers in our study possessed a test or shell, and settlers that died from causes other than overgrowth generally left an empty shell on the substratum. We rarely found empty shells or tests in the location of previously mapped settlers (less than $5 \%$ of the time), and if we did, those settlers were not considered to have been overgrown.

An additional factor that could have affected settlement patterns during our experiment was space limitation. If settlers were numerous enough, space for additional settlement could have become limited and further settlers excluded. However, space limitation should not have been a problem during our experiment as $<5 \%$ of available space was occupied by settlers. Additionally, on panels with established tunicates, adults occupied only $17.0 \pm 1.5 \%$ of total panel area at the end of the experiment.

At the end of our experiment we conducted 2 separate counts of settlers. In the first census, we counted all settlers on the entire panels. In the second census, which was made to determine whether there were finer scale responses in settlement than our entire panels surveys could detect, we counted all settlers within $1 \mathrm{~cm}$ of established tunicate colonies (areas around tunicates were defined by a pencil line drawn $1 \mathrm{~cm}$ from adults). On control panels during the second count, we counted settlers within a $4.5 \mathrm{~cm}$ diameter circle in the center of the panel; this circle represented the mean width of colonies on treatment panels, plus the $1 \mathrm{~cm}$ distance surrounding colonies.

To establish the size of tunicate colonies at the end of the experiment and the amount of area contained within the $1 \mathrm{~cm}$ radius around adults, the size of each colony and the $1 \mathrm{~cm}$ area around it were assessed with digital photographs and imaging as above.

Analysis. To determine the relative growth of tunicates during the study, we divided the size of each tunicate colony at the end of the experiment by the size of the colony at the initiation of the experiment. To determine the change in area covered by each tunicate colony (which is equivalent to the amount of surface area overgrown by each colony), we subtracted the area covered at the end of the experiment by the area covered at the initiation of the experiment for each colony. Differences in relative growth and change in area among tunicate species were evaluated with ANOVAs on square-root-transformed data with Tukey-Kramer post-hoc analyses.

We conducted independent pair-wise comparisons ( $t$-tests on raw untransformed data, $t$-tests on log-transformed data, or Mann-Whitney $U$-tests depending on whether data were normal and heteroscedastic) to determine whether there were differences in the number of settlers on available open space of entire panels between Botryllus and controls, Botrylloides and controls, and Diplosoma and controls. For our purposes it did not matter whether there were differences among all treatments (i.e. differences between Botryllus, Diplosoma, Botrylloides, and controls). Due to differences in the presence and size of established tunicate colonies, different treatments had different amounts of open space available for settlement. Therefore, to compare settlement between treatments, we obtained the relative numbers of settlers present per amount of open space for each panel. To derive settlement $\mathrm{cm}^{-2}$, the number of settlers was divided by the total amount of open space remaining on each panel at the end of the experiment. Pair-wise comparisons were only conducted for species with at least 50 larvae settling during the experiment.

We also conducted pair-wise comparisons (as above) to determine whether there were differences in the number of settlers found within $1 \mathrm{~cm}$ of established tunicate colonies relative to controls without tunicates. To compare differences in settlement between treatments, we divided the number of settlers found within $1 \mathrm{~cm}$ of established tunicates by the total amount of space available within $1 \mathrm{~cm}$ of established tunicates, or within the $4.5 \mathrm{~cm}$ diameter circle for control panels. Analyses were conducted only for species with at least 50 larvae settling during the experiment. 
A

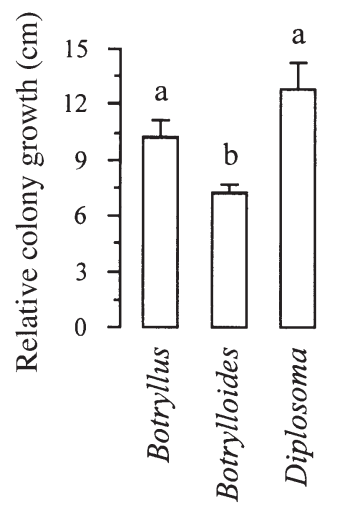

B

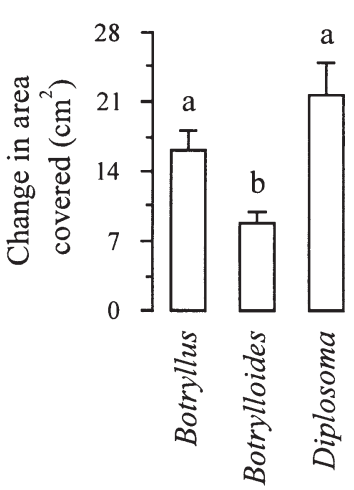

Fig. 1. Growth (means + SE) of established tunicate colonies during the $1 \mathrm{wk}$ experiment $(\mathrm{n}=19$ Botryllus, 19 Botrylloides, 16 Diplosoma). (A) Mean relative growth (end size/initial size) of tunicate colonies. (B) Mean change in area covered by tunicate colonies. Letters denote significant differences among treatments $(p<0.05$, Tukey-Kramer post-hoc analysis)

To determine whether there were differences in overgrowth of settlers by different tunicate species, we divided the number of settlers overgrown by each tunicate by the total surface area that each tunicate had overgrown during the experiment. Because all overgrowth data were non-normal, we used Kruskal-Wallis tests to evaluate among species differences in overgrowth of settlers. Analyses were conducted only for species which had more than 50 settlers overgrown.

\section{RESULTS}

During the 1 wk experiment, established colonies of Botrylloides grew significantly slower and covered significantly less area than Botryllus or Diplosoma (Fig. 1).

A total of 5200 larvae settled on our panels, 1406 of which settled within $1 \mathrm{~cm}$ of established adults (these values do not include Botryllus, Botrylloides, and Diplosoma settlers that were removed). Pair-wise compar-
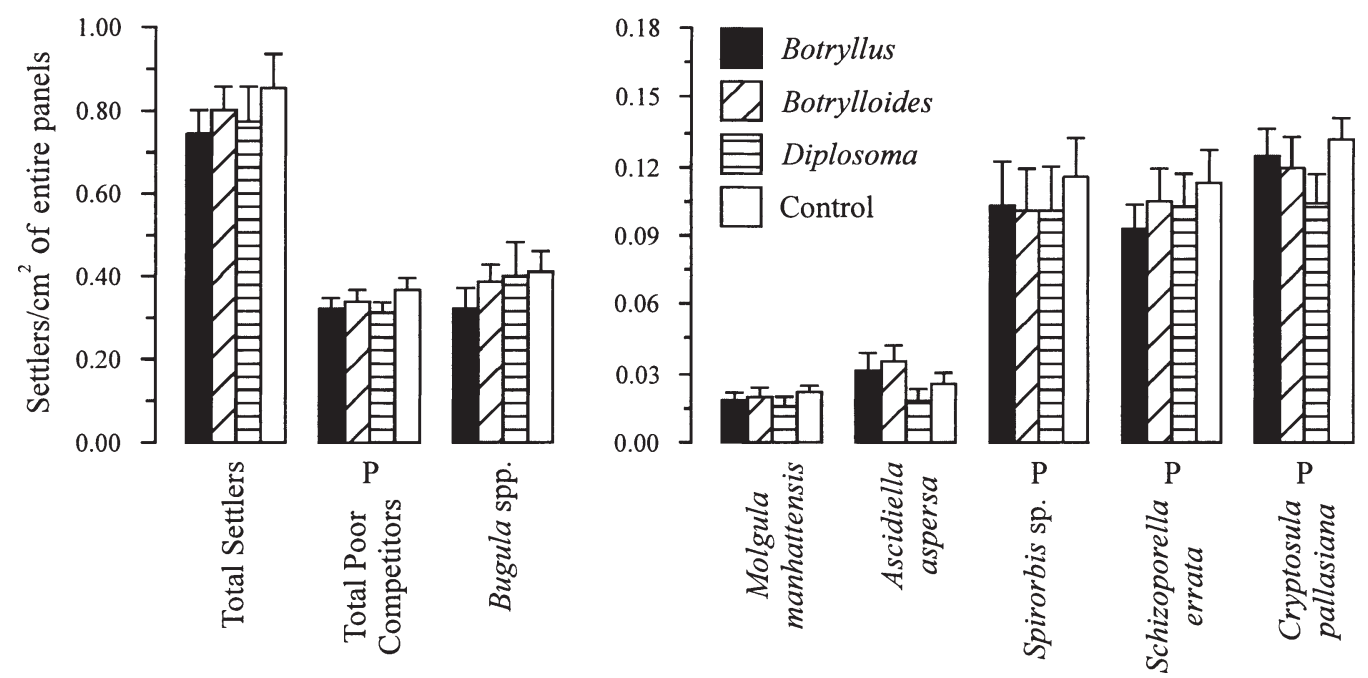

Fig. 2. Settlers per $\mathrm{cm}^{2}$ (mean $\left.+\mathrm{SE}\right)$ of available surface area on entire panels $(\mathrm{n}=19$ Botryllus, 19 Botrylloides, 16 Diplosoma, 20 control). ' $\mathrm{P}$ ' indicates a species which is an inferior spatial competitor as defined by Grosberg (1981). Data for 'Total Poor Competitors' also includes the relatively rare annelid Hydroides dianthus, 7 of which settled across all treatments. Note difference in $y$-axis scale between left and right panel

Table 1. Comparisons for settlers per $\mathrm{cm}^{2}$ of available surface area on entire panels. Numbers indicate p-values for pair-wise comparisons ( $t$-tests, $t$-tests on log-transformed data, or Mann-Whitney $U$-tests)

\begin{tabular}{|c|c|c|c|c|c|c|c|c|}
\hline \multirow{2}{*}{ Comparison } & \multirow[b]{2}{*}{ Total } & \multirow[b]{2}{*}{ Total Poor } & \multirow[b]{2}{*}{ Bugula spp. } & \multirow{2}{*}{$\begin{array}{c}\text { Molgula } \\
\text { Settlin } \\
\text { manhattensis }\end{array}$} & \multirow{2}{*}{$\begin{array}{l}\text { species } \\
\text { Ascidiella } \\
\text { aspersa }\end{array}$} & \multirow[b]{2}{*}{$\begin{array}{l}\text { Spirorbis } \\
\text { spp. }\end{array}$} & \multirow[b]{2}{*}{$\begin{array}{c}\text { Schizoporella } \\
\text { errata }\end{array}$} & \multirow[b]{2}{*}{$\begin{array}{l}\text { Cryptosula } \\
\text { pallasiana }\end{array}$} \\
\hline & & & & & & & & \\
\hline Botryllus vs. Control & 0.227 & 0.330 & 0.182 & 0.334 & 0.680 & 0.572 & 0.274 & 0.588 \\
\hline Botrylloides vs. Control & 0.911 & 0.388 & 0.910 & 0.584 & 0.189 & 0.375 & 0.723 & 0.441 \\
\hline Diplosoma vs. Control & 0.300 & 0.174 & 0.822 & 0.197 & 0.262 & 0.559 & 0.573 & 0.052 \\
\hline
\end{tabular}



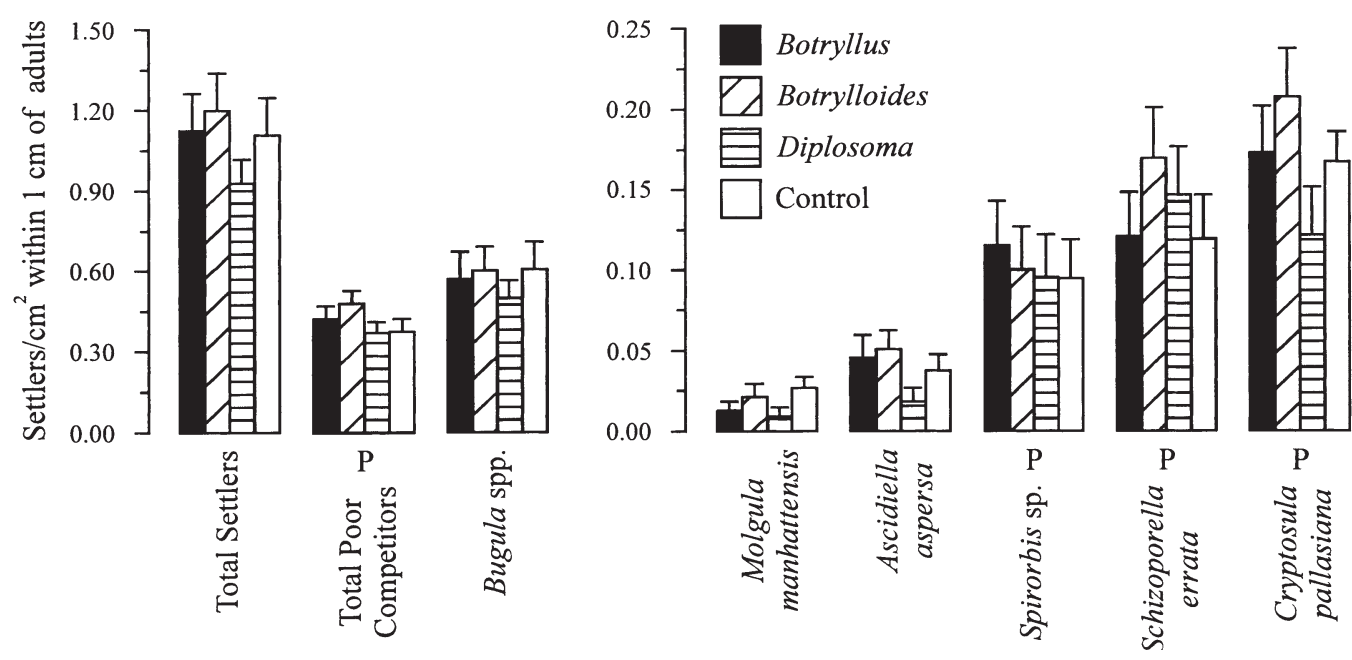

Fig. 3. Settlers per $\mathrm{cm}^{2}$ (mean $+\mathrm{SE}$ ) of available surface area within $1 \mathrm{~cm}$ of established tunicate colonies or within a $4.5 \mathrm{~cm}$ diameter central circle for controls ( $\mathrm{n}=19$ Botryllus, 19 Botrylloides, 16 Diplosoma, 20 control). ' $\mathrm{P}$ ' indicates a species which is an inferior spatial competitor as defined by Grosberg (1981). Data for 'Total Poor Competitors' also includes Hydroides dianthus, 5 of which settled across all treatments. Note difference in $y$-axis scale between left and right panel

isons revealed no between-treatment differences in larval settlement in entire panel analyses (Fig. 2, Table 1), and only 1 difference within $1 \mathrm{~cm}$ of established tunicates (Fig. 3, Table 2). The only significant difference detected was for fewer larvae of the solitary tunicate Molgula manhattensis to settle within $1 \mathrm{~cm}$ of Diplosoma colonies relative to controls $(p=0.033)$ (Fig. 3 , Table 2). Strong trends, however, were detected for there to be fewer settlers of the bryozoan Cryptosula pallasiana on panels with Diplosoma, both on entire panels and within $1 \mathrm{~cm}$ of colonies, relative to controls ( $p=0.052$ and $p=0.051$ respectively) (Figs. $2 \& 3$ ). All other tests were non-significant.

A total of 300 settlers were overgrown by adult tunicates. There was no difference in the number of settlers overgrown for any settling species by different tunicate species (Fig. 4).

\section{DISCUSSION}

Larvae of many marine invertebrates actively select among sites during settlement (Pawlik 1992, Underwood \& Keough 2001) and have previously been shown to avoid settling near established adults of superior competitors (e.g. Grosberg 1981, Young \& Chia 1981). However, when we compared the levels of larval settlement on panels with established tunicates relative to control panels without tunicates, we found that larvae did not avoid settling near established colonies of the tunicates Botryllus, Botrylloides, or Diplosoma (Figs. $2 \& 3$ ). Thus, our results suggest that settling larvae do not avoid settling near dominant competitors. These results are in contrast to a previous study (Grosberg 1981) that showed that larvae of competitively inferior species (i.e. the polychaete Spirorbis sp. and the bryozoans Cryptosula pallasiana and Schizoporella errata) avoided settling near Botryllus.

We conducted pair-wise comparisons of settlement on panels with individual tunicate species relative to controls without tunicates. Because numerous species settled on our panels, and because we pooled data for

Table 2. Comparisons of settlers per $\mathrm{cm}^{2}$ of available surface area within $1 \mathrm{~cm}$ of established tunicate colonies or within a $4.5 \mathrm{~cm}$ diameter central circle for controls. Numbers indicate $p$-values for pair-wise comparisons ( $t$-tests, $t$-tests on log transformed data, or Mann-Whitney $U$-tests)

\begin{tabular}{|c|c|c|c|c|c|c|c|c|}
\hline \multirow{2}{*}{ Comparison } & \multirow[b]{2}{*}{ Total } & \multirow[b]{2}{*}{ Total Poor } & \multirow[b]{2}{*}{ Bugula spp. } & \multirow{2}{*}{$\begin{array}{c}\text { Molgula } \\
\text { Settling } \\
\text { manhattensis }\end{array}$} & \multirow{2}{*}{$\begin{array}{l}\text { species } \\
\text { Ascidiella } \\
\text { aspersa }\end{array}$} & \multirow[b]{2}{*}{$\begin{array}{l}\text { Spirorbis } \\
\text { spp. }\end{array}$} & \multirow[b]{2}{*}{$\begin{array}{c}\text { Schizoporella } \\
\text { errata }\end{array}$} & \multirow[b]{2}{*}{$\begin{array}{l}\text { Cryptosula } \\
\text { pallasiana }\end{array}$} \\
\hline & & & & & & & & \\
\hline Botryllus vs. Control & 0.633 & 0.526 & 0.793 & 0.103 & 0.823 & 0.753 & 0.876 & 0.849 \\
\hline Botrylloides vs. Control & 0.292 & 0.205 & 0.849 & 0.496 & 0.294 & 0.932 & 0.203 & 0.277 \\
\hline Diplosoma vs. Control & 0.621 & 0.975 & 0.584 & 0.033 & 0.239 & 0.935 & 0.470 & 0.051 \\
\hline
\end{tabular}




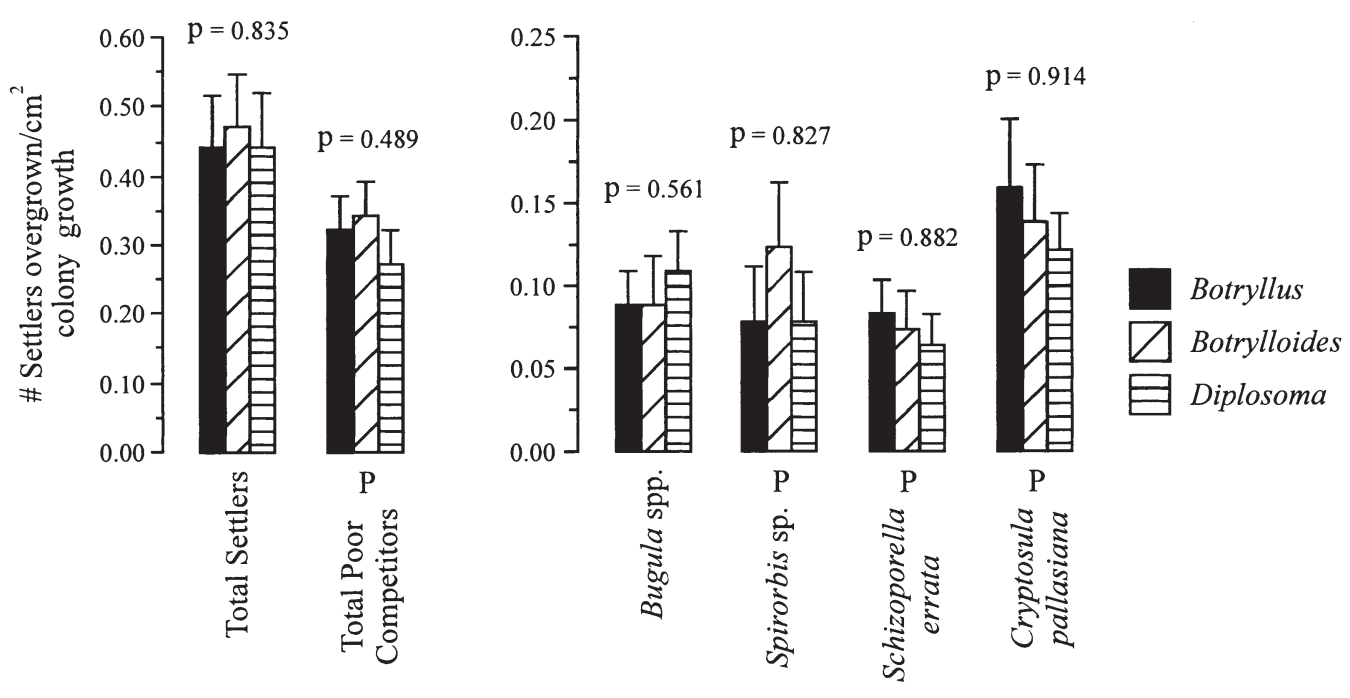

Fig. 4. Overgrown settlers per $\mathrm{cm}^{2}$ (mean $\left.+\mathrm{SE}\right)$ of colony growth $(\mathrm{n}=19$ Botryllus, 19 Botrylloides, 16 Diplosoma). ' $\mathrm{P}$ ' indicates a species which is an inferior spatial competitor as defined by Grosberg (1981). Data for 'Total Poor Competitors' also includes Hydroides dianthus, 1 of which was overgrown by an established Botrylloides colony. p-values are for comparisons among all treatments (Kruskal-Wallis tests)

all settlers and for settlers of competitively inferior species, we conducted a total of 48 individual pair-wise settlement comparisons. From these analyses, however, we detected only 1 significant difference, that there were fewer Molgula manhattensis settlers within $1 \mathrm{~cm}$ of Diplosoma colonies than on controls. All other tests were non-significant.

In addition to finding fewer Molgula manhattensis settlers within $1 \mathrm{~cm}$ of Diplosoma colonies, we also detected strong trends for there to be fewer Cryptosula pallasiana settlers on Diplosoma panels, both on entire panels and within $1 \mathrm{~cm}$ of colonies. Diplosoma is unique among the tunicates we examined because its tunic is extremely acidic $(\mathrm{pH}=1, \mathrm{~S}$. G. Bullard unpubl. data). Many ascidians possess an acidic tunic which may function to deter predators (Pisut \& Pawlik 2002) or retard larval settlers (Stoecker 1978, but see also Davis \& Wright 1989). It is therefore tempting to suggest that some larvae may avoid settling near Diplosoma because of its acidic tunic. However, because of the large number of analyses we conducted (48 pairwise comparisons), it is also possible that these few negative interactions have minimal biological significance. Support for this idea comes from the fact that there were no significant differences in total settlers or in total settlers of competitively inferior species on Diplosoma panels relative to controls.

The proposed reason for why larvae might avoid settling near established adults is that newly settled juveniles might be at risk of overgrowth from established adults (Grosberg 1981, Young \& Chia 1981). When we followed the number and species of settlers that were overgrown by different tunicates, we found no differences in the overgrowth of any species of settler by any of our tunicate species (Fig. 4). Thus, all of the tunicates we examined seemed to possess similar post-settlement risks to newly settled larvae. This was true even though Botrylloides grew significantly slower than our other tunicate species (Fig. 1) (but see Stachowicz et al. 2002 for additional growth rate estimates).

Our results differed from those of Grosberg (1981) who found that larvae of competitively inferior species avoided settling on panels with 15 juvenile Botryllus colonies. Because Grosberg's study and ours made use of the same suite of settling larvae and were conducted for the same length of time, it is unclear why our results differ. However, several possible factors could have contributed to the differences found by our studies.

One difference between our study and Grosberg's (1981) was that Grosberg used $1 \mathrm{~d}$ old Botryllus juveniles while we used adult colonies. If larvae avoided Botryllus in Grosberg's study because they detected a negative settlement cue released by Botryllus, it is possible that only juvenile Botryllus colonies release this cue. If so, this could provide Botryllus with a significant competitive advantage because larvae of potential competitors would avoid Botryllus while it is small and presumably more vulnerable to spatial competitors. Ontogenetic differences in chemical defense have been documented in some benthic species including tunicates (Uriz et al. 1996, Tarjuelo et al. 2002; see also Lindquist 2002). However, the hypothesis that Botryllus releases a negative settlement cue that varies ontogenetically remains untested and, because these types of defenses are likely rare, must be considered a non- 
parsimonious explanation for our observations. Additionally, ontogenetic differences in chemical cue production would not explain why only larvae of competitively inferior species avoided Botryllus in Grosberg's (1981) study. If Botryllus juveniles did produce a negative cue, one would expect the cue to inhibit dominant competitors rather than inferior competitors.

A second potential explanation for the observed differences between the 2 studies could be related to the number of Botryllus colonies attached to each panel. Grosberg used substrata with either 5 or 15 established juvenile colonies while we used substrata with a single established adult colony. Because Grosberg (1981) only found reduced settlement on panels with 15 juvenile Botryllus, a minimum density threshold may need to be reached before larvae respond to the presence of Botryllus. If so, this threshold may not have been reached in our study. This seems unlikely, however, considering the size of the adult colonies used in our study. By the end of our experiment the mean size of our Botryllus colonies was $18.23 \pm 2.00 \mathrm{~cm}^{2}$. Although the size of the juvenile colonies used by Grosberg (1981) is not stated, $1 \mathrm{~d}$ old juvenile Botryllus colonies are typically several $\mathrm{mm}^{2}$ in size. Therefore, if a negative settlement cue is produced by Botryllus and its release is proportional to colony size, it is unlikely that less cue would be released by a single adult colony versus 15 juvenile colonies.

Other untested factors may also have contributed to the differences in settlement patterns between the 2 studies. For example, the hydrodynamics of the 2 studies sites might have influenced the way larvae discriminated among settlement sites (e.g. Butman 1987); physiological or ecological differences could exist between the Massachusetts and Connecticut populations of Botryllus or other fouling organisms that affected settlement patterns; complex interactions might exist between established adults, newly settled juveniles, and settling larvae, and might be density-dependent; etc. While we cannot provide an unequivocal explanation for the differences between the 2 studies, considering the scale of our study ( $\mathrm{n}=16$ to 20 replicate panels in ours compared to $\mathrm{n}=3$ in Grosberg's 1981 study) coupled with the fact that we examined settlement patterns over entire panels and within $1 \mathrm{~cm}$ of established colonies (compared to only entire panel assessments made by Grosberg 1981), if differences in settlement had existed during our study we should have detected them.

Additionally, the results of our current study are comparable to the results of a similar preliminary study we conducted during July 2000. The methods of our preliminary study were identical to this study, but had $\mathrm{n}=10$ rather than $\mathrm{n}=20$ replicate panels. In our preliminary study we found no significant differences in settlement on tunicate versus control panels in entire panel analyses (Table 3). However, we found 3 significant differences out of 21 analyses in settlement within $1 \mathrm{~cm}$ of tunicates relative to controls (Table 4). We also found several trends for significant differences in

Table 3. Comparisons for settlers per $\mathrm{cm}^{2}$ of available surface area on entire panels. From preliminary experiment conducted in 2000. Numbers indicate $p$-values for pair-wise comparisons ( $t$-tests or Mann-Whitney $U$-tests). Sample size = 8 Botryllus, 10 Botrylloides, 10 Diplosoma, 9 controls. NA = not tested because fewer than 50 total individuals settled

\begin{tabular}{|c|c|c|c|c|c|c|c|c|}
\hline \multirow[t]{2}{*}{ Comparison } & \multirow[b]{2}{*}{ Total } & \multirow[b]{2}{*}{ Total Poor } & \multirow[b]{2}{*}{ Bugula spp. } & \multirow{2}{*}{$\begin{array}{c}\text { Molgula } \\
\text { Manhattensis } \\
\text { mang }\end{array}$} & \multirow{2}{*}{$\begin{array}{l}\text { species } \\
\text { Ascidiella } \\
\text { aspersa }\end{array}$} & \multirow[b]{2}{*}{$\begin{array}{l}\text { Spirorbis } \\
\text { spp. }\end{array}$} & \multirow[b]{2}{*}{$\begin{array}{c}\text { Schizoporella } \\
\text { errata }\end{array}$} & \multirow[b]{2}{*}{$\begin{array}{l}\text { Cryptosula } \\
\text { pallasiana }\end{array}$} \\
\hline & & & & & & & & \\
\hline Botryllus vs. Control & 0.261 & 0.477 & 0.538 & NA & 0.236 & 0.577 & 0.699 & 0.325 \\
\hline Botrylloides vs. Control & 0.147 & 0.331 & 0.077 & NA & 0.147 & 0.407 & 0.435 & 0.483 \\
\hline Diplosoma vs. Control & 0.072 & 0.158 & 0.128 & NA & 0.775 & 0.279 & 0.176 & 0.127 \\
\hline
\end{tabular}

Table 4. Comparisons of settlers per $\mathrm{cm}^{2}$ of available surface area within $1 \mathrm{~cm}$ of established tunicate colonies or within a $2.5 \mathrm{~cm}$ diameter central circle for controls. From preliminary experiment conducted in 2000. The control diameter is smaller than in Table 2 because the mean tunicate ending size was smaller in this experiment. Numbers indicate p-values for pair-wise comparisons ( $t$-tests, $t$-tests on log-transformed data, or Mann-Whitney $U$-tests). Sample size $=8$ Botryllus, 10 Botrylloides, 10 Diplosoma, 9 control. NA $=$ not tested because fewer than 50 total individuals settled

\begin{tabular}{|c|c|c|c|c|c|c|c|c|}
\hline \multirow{2}{*}{ Comparison } & \multirow[b]{2}{*}{ Total } & \multirow[b]{2}{*}{ Total Poor } & \multirow[b]{2}{*}{ Bugula spp. } & \multirow{2}{*}{$\begin{array}{c}\text { Molgula } \\
\text { Settling } \\
\text { manhattensis }\end{array}$} & \multirow{2}{*}{$\begin{array}{l}\text { species } \\
\text { Ascidiella } \\
\text { aspersa }\end{array}$} & \multirow[b]{2}{*}{$\begin{array}{l}\text { Spirorbis } \\
\text { spp. }\end{array}$} & \multirow[b]{2}{*}{$\begin{array}{c}\text { Schizoporella } \\
\text { errata }\end{array}$} & \multirow[b]{2}{*}{$\begin{array}{l}\text { Cryptosula } \\
\text { pallasiana }\end{array}$} \\
\hline & & & & & & & & \\
\hline Botryllus vs. Control & 0.070 & 0.319 & 0.127 & NA & 0.291 & 0.305 & 0.810 & 0.756 \\
\hline Botrylloides vs. Control & 0.002 & 0.095 & 0.027 & NA & 0.303 & 0.024 & 0.623 & 0.518 \\
\hline Diplosoma vs. Control & 0.154 & 0.416 & 0.073 & NA & 0.801 & 0.059 & 0.973 & 0.424 \\
\hline
\end{tabular}


entire panel and within $1 \mathrm{~cm}$ analyses (6 out of 42 analyses) (Tables $3 \& 4$ ). In each case of significant response or trend, however, higher settlement occurred on tunicate panels or within $1 \mathrm{~cm}$ of tunicates than on controls. Thus, these preliminary results also refute the idea that settling larvae avoid superior competitors and suggest that larvae may occasionally preferentially settle near competitors.

We note that we conducted the larger experiment $(\mathrm{n}=$ 20 replicate panels) because low statistical power in our preliminary experiment $(n=10)$ precluded us determining the biological significance of trends noticed in the preliminary experiment. A few differences exist between the larger and preliminary experiments. For example, there are several instances in the preliminary experiment of higher settlement occurring within $1 \mathrm{~cm}$ of Botrylloides than on controls. In the larger experiment no differences in settlement were detected between Botrylloides and control panels. Due to the larger sample size in the larger study, we view its results as more reflective of the true biological response of settling larvae.

Additional work should be conducted to determine whether settling larvae can detect the presence of dominant competitors on the substratum in general. Direct evidence for the idea that larvae avoid superior competitors during settlement comes from a limited number of studies (i.e. Grosberg 1981, Young \& Chia 1981). Other studies (e.g. Osman \& Whitlatch 1995a, Pineda \& Caswell 1997) have shown that larvae of many benthic species generally avoid settling directly on resident adult organisms and that spatial variations in larval settlement patterns can be a function of the amount of open space available. Additionally, Keough (1998) found that previously settled juveniles had little effect on subsequent larval settlement. Thus, further testing is needed to determine whether the previously documented cases of competitor avoidance by settling larvae are isolated exceptions or the norm.

Work should also be conducted to determine whether different taxa of established competitors elicit different responses from settling larvae and if the ecological history of species affect settlement patterns. Both of the earlier studies (Grosberg 1981, Young \& Chia 1981) and the present study used colonial tunicates as dominant competitors. Additionally, 2 of the colonial tunicates used in the present study are invasive and potentially unfamiliar to native larvae. Thus, it remains unclear if settling larvae respond differently to different taxa of benthic organisms (e.g. sponges, hydroids, bryozoans, etc.) and if native larvae respond differently to invasive competitors.

Acknowledgements. Funding for this project was provided by NSF grants OCE98199489, OCE9901139, and OCE0002251. We thank K. Barber, K. Heinonen, and H. Fried for help with field work. Comments by R. K. Grosberg, E. I. Collins, S. E. Koch, and 4 anonymous reviewer improved the manuscript.

\section{LITERATURE CITED}

Barnes DKA (2002) Polarization of competition increases with latitude. Proc R Soc Lond B 269:2061-2069

Barnett BE, Crisp DJ (1979) Laboratory studies of gregarious settlement in Balanus balanoides and Elminius modestus in relation to competition between these species. J Mar Biol Assoc UK 59:581-590

Branch GM (1984) Competition between marine organisms: ecological and evolutionary implications. Oceanogr Mar Biol Annu Rev 22:429-593

Butman CA (1987) Larval settlement of soft-sediment invertebrates: the spatial scales of pattern explained by active habitat selection and the emerging role of hydrodynamical processes. Oceanogr Mar Biol Annu Rev 25:113-165

Connell JH (1961) The influence of interspecific competition and other factors on the distribution of the barnacle Chthamalus stellatus. Ecology 42:710-723

Davis AR, Wright AE (1989) Interspecific differences in fouling of 2 congeneric ascidians Eudistoma olivaceum, E. capsulatum: is surface acidity an effective defense? Mar Biol 102:491-497

Dunstan PK, Johnson CR (2004) Invasion rates increase with species richness in a marine epibenthic community by 2 mechanisms. Oecologia 138:285-292

Engel S, Pawlik JR (2000) Allelopathic activities of sponge extracts. Mar Ecol Prog Ser 207:273-281

Grosberg RK (1981) Competitive ability influences habitat choice in marine invertebrates. Nature 290:700-702

Hadfield MG, Paul VJ (2001) Natural chemical cues for settlement and metamorphosis of marine-invertebrate larvae. In: McClintock JB, Baker BJ (eds) Marine chemical ecology. CRC Press, Boca Raton, FL, p 431-461

Hunt HL, Scheibling RE (1997) Role of early post-settlement mortality in recruitment of benthic marine invertebrates. Mar Ecol Prog Ser 155:269-301

Hurlbut CJ (1993) The adaptive value of larval behavior of a colonial ascidian. Mar Biol 115:253-262

Johnson LE, Strathmann RR (1989) Settling barnacle larvae avoid substrata previously occupied by a mobile predator. J Exp Mar Biol Ecol 128:87-103

Keough MJ (1998) Responses of settling invertebrate larvae to the presence of established recruits. J Exp Mar Biol Ecol 231:1-19

Keough MJ, Downes BJ (1982) Recruitment of marine invertebrates: the role of active larval choices and early mortality. Oecologia 54:348-353

Kingsford MJ, Leis JM, Shanks A, Lindeman KC, Morgan SG, Pineda J (2002) Sensory environments, larval abilities and local self-recruitment. Bull Mar Sci (Suppl S) 70:309-340

Koh EGL, Sweatman H (2000) Chemical warfare among scleractinians: bioactive natural products from Tubastraea faulkneri Wells kill larvae of potential competitors. J Exp Mar Biol Ecol 251:141-160

Krug PJ, Manzi AE (1999) Waterborne and surface-associated carbohydrates as settlement cues for larvae of the specialist marine herbivore Alderia modesta. Biol Bull (Woods Hole) 197:94-103

Lindquist N (2002) Chemical defense of early life stages of benthic marine invertebrates. J Chem Ecol 28:1987-2000

Maldonado M, Uriz MJ (1998) Microrefuge exploitation by subtidal encrusting sponges: patterns of settlement and post-settlement survival. Mar Ecol Prog Ser 174:141-150

Meadows PS, Campbell JI (1972) Habitat selection by aquatic invertebrates. Adv Mar Biol 10:271-382

Nandakumar K (1996) Importance of timing of panel exposure on the competitive outcome and succession of sessile 
organisms. Mar Ecol Prog Ser 131:191-203

Osman RW, Whitlatch RB (1995a) The influence of resident adults on recruitment: a comparison to settlement. J Exp Mar Biol Ecol 190:169-198

Osman RW, Whitlatch RB (1995b) The influence of resident adults on larval settlement: experiments with four species of ascidians. J Exp Mar Biol Ecol 190:199-220

Pawlik JR (1992) Chemical ecology of the settlement of benthic marine invertebrates. Oceanogr Mar Biol Annu Rev 30:273-335

Pechenik JA (1999) On the advantages and disadvantages of larval stages in benthic marine invertebrate life cycles. Mar Ecol Prog Ser 177:269-297

Pineda J, Caswell H (1997) Dependence of settlement rate on suitable substrate area. Mar Biol 129:541-548

Pisut DP, Pawlik JR (2002) Anti-predatory chemical defenses of ascidians: secondary metabolites or inorganic acids? J Exp Mar Biol Ecol 270:203-214

Sebens KP (1986) Spatial relationships among encrusting marine organisms in the New England subtidal zone. Ecol Monogr 56:73-96

Stachowicz JJ, Terwin JR, Whitlatch RB, Osman RW (2002) Linking climate change and biological invasions: ocean warming facilitates nonidigenous species invasions. Proc Natl Acad Sci USA 99:15497-15500

Stebbing ARD (1972) Preferential settlement of a bryozoan and serpulid larvae on the younger parts of Laminaria fronds. J Mar Biol Assoc UK 52:765-772

Steneck RS, Carlton JT (2001) Human alterations of marine communities: students beware! In: Bertness MD, Gaines SD, Hay ME (eds) Marine community ecology. Sinauer Associates, Sunderland, MA, p 445-468

Stoecker D (1978) Resistance of a tunicate to fouling. Biol Bull

Editorial responsibility: Otto Kinne (Editor),

Oldendorf/Luhe, Germany
(Woods Hole) 155:615-626

Stoner DS (1990) Recruitment of a tropical colonial ascidian: relative importance of pre-settlement vs. post settlement processes. Ecology 71:1682-1690

Stoner DS (1994) Larvae of a colonial ascidian use a noncontact mode of substratum selection on a coral-reef. Mar Biol 121:319-326

Tarjuelo I, Lopez-Legentil S, Codina M, Turon X (2002) Defence mechanisms of adults and larvae of colonial ascidians: patterns of palatability and toxicity. Mar Ecol Prog Ser 235:103-115

Thacker RW, Becerro MA, Lumbang WA, Paul VJ (1998) Allelopathic interactions between sponges on a tropical reef. Ecology 79:1740-1750

Toonen RJ, Pawlik JR (1996) Settlement of the tube worm Hydroides dianthus (Polychaeta: Serpulidae): cues for gregarious settlement. Mar Biol 126:725-733

Underwood AJ, Keough MJ (2001) Supply-side ecology: the nature and consequences of variation in recruitment of intertidal organisms. In: Bertness MD, Gaines SD, Hay ME (eds) Marine community ecology. Sinauer Associates, Sunderland, MA, p 183-200

Uriz MJ, Turon X, Becerro MA, Galera J (1996) Feeding deterrence in sponges: the role of toxicity, physical defenses, energetic contents, and life-history stage. J Exp Mar Biol Ecol 205:187-204

Witman JD, Dayton PK (2001) Rocky subtidal communities. In: Bertness MD, Gaines SD, Hay ME (eds) Marine community Ecology. Sinauer Associates, Sunderland, MA, p 339-366

Young CM, Chia FS (1981) Laboratory evidence for delay of larval settlement in response to a dominant competitor. Int J Invertebr Reprod 3:221-226

Submitted: September 22, 2003; Accepted: June 15, 2004 Proofs received from author(s): October 6, 2004 